\title{
HFE gene polymorphisms and the risk for autism in Egyptian children and impact on the effect of oxidative stress
}

\author{
Ola H. Gebril* and Nagwa A. Meguid \\ Department of Research on children with special needs, National Research Centre, Cairo, Egypt
}

\begin{abstract}
Background: Autism is among the commonest neurodevelopmental childhood disorders worldwide; its aetiology is still unknown. Iron metabolism alteration in the central nervous system is recently implicated as a risk factor for several neurodegenerative disorders.

Haemochromatosis HFE gene polymorphisms (p.H63D and p.C282Y) have shown significant association with several neurological diseases. Some evidences show altered iron related proteins in serum of autistic children. The aim of this work is to conduct a preliminary pilot study for the association of HFE polymorphisms and autism.

Methods: All cases were referred from the clinic of special needs, National Research Centre, Cairo. Clinical diagnosis was based on the criteria for autistic disorder as defined in the Diagnostic and Statistical Manual of Mental Disorders Fourth Edition, Text Revision (DSM-IV-TR).

Whole genome DNA was extracted; p.H63D and p.C282Y genotyping was studied using specific sequence amplification followed by restriction enzyme digestion on a sample of autism patients ( 25 cases) and twenty controls.

Results: The p.H63D is more abundant than the $\mathrm{C} 282 \mathrm{Y}$ among both autism and control samples. No significant association of p.H63D nor p.C282Y polymorphism and autism was revealed.

Conclusion: We here report on the first pilot study of the possible genetic association between autism and HFE gene polymorphisms among Egyptians. Although our results do not prove the role of HFE polymorphisms as risk factors for autism, yet this does not exclude the role of iron in this prevalent disorder. Further extended studies are recommended to include other iron metabolism genes.
\end{abstract}

Keywords: Neurodevelopmental disorders, Iron, haemochromatosis, genes, polymorphisms

\section{Introduction}

Autism or autistic spectrum disorder is complex behavioral phenotypes with multigenic aetiology of increasingly significance among Paediatrics neurodevelopmental disorders. Its incidence increases before 3 years of age [26], while, recently, the prevalence estimates are in the range of 6.5 to 6.6 per 1,000 [12]. The increase in the rate of autism as revealed by epidemiological studies and government reports implicates the

\footnotetext{
*Corresponding author: Dr/Ola Hosny Gebril, Department Research on children with special Needs, National Research Centre, Dokki, Cairo, Egypt. Tel.: +20 2 38351118; Fax: +20 2 33370931; E-mail: olahossny@hotmail.com.
}

importance of external or environmental factors that might be changing [20].

According to the Diagnostic and Statistical Manual of Mental Disorders, Fourth Edition, and International Classification of Diseases, Tenth Revision classifications, autism is Characterized by impairments in social interaction, language, communication, and imaginative play $[5,6]$.

Recently, trace elements are implicated as potential risk factors for autism, with iron being one of the mostly studied trace element that maintains the integrity and functioning of the central nervous system. Oxidative stress has been shown to play a major role in the development of several neurological diseases as Alzheimer disease's AD, Parkinson disease, and schizophrenia [34]. The Iron has been considered a 
major potential source of increased production of ROS, leading to glioneuronal injury in the CNS, ferrous iron contributes to oxidative stress by catalyzing the conversion of hydrogen peroxide to highly toxic hydroxyl radicals through the Fenton reaction [32].

Other antioxidant proteins namely Ceruloplamin and transferrin have been studied in autistic children, with their levels being reduced compared to normal siblings [36]. These proteins are synthesized in the brain, with ceruloplasmin being a ferroxidase that protects cell membranes from active oxygen radicals, with transportation of iron to cells being a main function [13]. Transferrin is present in serum and other body fluids, with a main function to transport iron to proliferating cells [21].

$H F E$ is a major histocompatability complex (MHC) class I-like gene [8]. The HFE protein combines with b2-microglobulin (B2M) and to compete with transferrin (Tf) for binding to the transferring receptor (TfR). Functioning normally it exerts inhibitory regulation on the endocytosis of iron $[9,25]$. Two common HFE single nucleotide polymorphisms (SNP) exist (p.H63D; p.C282Y), with highest frequencies being in Caucasian populations [22]. A previous study showed that the $\mathrm{Y}$ allele of the $\mathrm{C} 282 \mathrm{Y}$ polymorphism was absent in Egyptian while the frequency of the D allele of H63D polymorphism was around $11 \%$ (3).

In the present study, polymorphisms in the HFE gene were selected as candidate genetic risk factors for autism because of their known biological effects on iron metabolism.

\section{Materials and methods}

\subsection{Study participants}

The study included 26 patients with autism, they were referred to the clinic of children with special needs, NRC. Their age ranged between 5-15 years (mean age of 6.6 years \pm 4.4 ), with male gender being more abundant among the studied cases ( 24 males, 2 females), with diagnosis of autism being confirmed by DSM IV edition.

A Control sample consisting of neurologically normal children (25 samples) within the same age range was studied. The cases were invited to participate in the study and a Research Ethics Committee of the National research Centre approved all procedures for blood donation and research.

The blood ferritin level in autism and control children ranged from 25-49 ng/ml. No significant difference between both groups was detected, with a $\mathrm{p}$ value of 0.4 .
Table 1

p.H63D genotyping (percentages) among the studied cases

\begin{tabular}{lcc}
\hline p.H63D & Autism cases & Control \\
\hline H/H & $22(88 \%)$ & $17(85 \%)$ \\
H/D & $2(8 \%)$ & $3(15 \%)$ \\
D/D & $1(4 \%)$ & $0(0 \%)$ \\
\hline
\end{tabular}

\subsection{Genotyping}

Blood was collected in EDTA containing tubes for DNA extraction. Genomic DNA was isolated by standard procedures using the DNA extraction kit (Qiagen).

PCR was carried out using primers sequences and annealing temperatures shown in Table 1 . The PCR reaction mixture was composed of: 50ng DNA, 10pmol forward primer, $10 \mathrm{pmol}$ reverse primer, $10 \mu \mathrm{l}$ of $2 \mathrm{x}$ Reddy Mix (AbGene) and nuclease free water (final volume $20 \mu \mathrm{l})$. The cyclic parameters to study the p.H63D mutation were 5 minutes at $95^{\circ} \mathrm{C}$, followed by 35 cycles of 30 seconds at $95^{\circ} \mathrm{C}, 30$ seconds at $57^{\circ} \mathrm{C}$ and 45 seconds at $72^{\circ} \mathrm{C}$, ending with a final $72^{\circ} \mathrm{C}$ for 10 minutes. For the $H F E$ p.C282Y polymorphism the same cycling conditions were used but HFE p.C282Y annealed at $55^{\circ} \mathrm{C}$, as previously described.

The candidate SNPs were identified using optimized restriction endonucleases mixtures: MboI (New England Biolabs) for p.H63D and RsaI (New England Biolabs) for p.C282Y, as described previously (31).The digestion products were electrophorized on $3 \%$ agarose gels, and the digestion products were visualized by ethidium bromide staining.

All Statistical analysis was done using the SPSS version 14 software package. $\chi^{2}$ testing was used to evaluate the association between gene polymorphisms and autism. P-values of 0.05 were considered statistically significant. Multinomial logistic regression was used to study interacting factors e.g. sex effect on genotyping.

\section{Results}

\section{1. p.H63D genotyping}

The H63D PCR products (210 bp) were used for genotyping (Fig. 1). p.H63D genotyping data on $3 \%$ agarose gel was performed, The $\mathrm{H}$ allele was cut into three fragments of 98,63 , and $49 \mathrm{bp}$, while the D allele was cut into two fragments of 147 and $63 \mathrm{bp}$.

In autism group, there is one homozygous case $\mathrm{D} / \mathrm{D}$, 2 heterozygous $\mathrm{H} / \mathrm{D}$ cases and 22 case are wild $\mathrm{H} / \mathrm{H}$, while in the control group there is no homozygote $\mathrm{D} / \mathrm{D}$, 


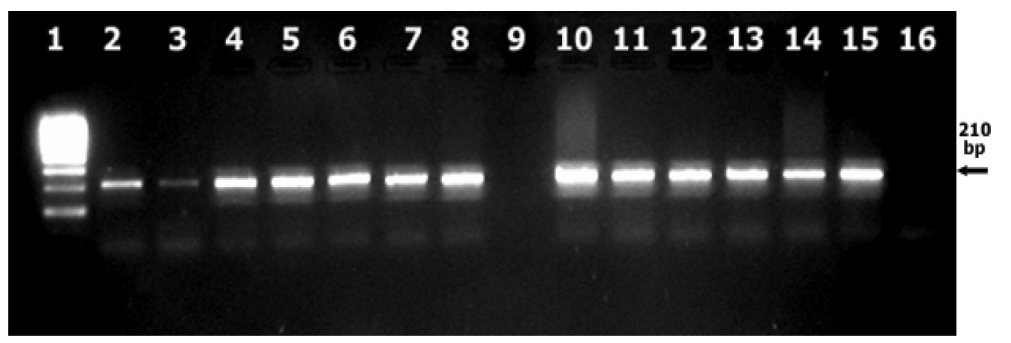

Fig. 1. HFE H63D PCR electrophoresis on 2.5\% agarose gel, Lane 1 is hyperladder IV, lane 2-8 and 10-15 are H63D PCR products, lane 9 is an empty well and lane 16 is a - ve control PCR (without DNA).

Table 2 p.C282Y genotyping among the studied cases

\begin{tabular}{lcc}
\hline p.C282Y & Autism cases & Control \\
\hline $\mathrm{C} / \mathrm{C}$ & 25 & 19 \\
$\mathrm{C} / \mathrm{Y}$ & 0 & 1 \\
$\mathrm{Y} / \mathrm{Y}$ & 0 & 0 \\
\hline Total & 25 & 20 \\
\hline
\end{tabular}

3 heterozygotes $\mathrm{H} / \mathrm{D}$ and the rest are wild type $\mathrm{H} / \mathrm{H}$ (Table 1).

The $\mathrm{H} 63$ allele frequency in autism cases is $92 \%$, the D 63 allele frequency is $8 \%$. In the control group, the $\mathrm{H} 63$ allele frequency is $92.5 \%$ and the D 63 allele frequency is $7.5 \%$. The distribution of the D 63 allele is shown to be less abundant compared to frequencies in Caucasian populations which showed frequencies around $20 \%$ [1].

The alleles frequencies are in Hardy-Weinberg equilibrium. Chi-square test does not show significant association of the D allele with autism $(p=0.13)$.

\section{2. p.C282Y genotyping}

The p.C282Y PCR products (320 bp) were used for genotyping (Fig. 2).

The genotyping of the rare allele p.C282Y was determined by running the Rsal digestion products on $3 \%$ agarose gel. The $\mathrm{C}$ allele is cut in two fragments of 261 and $59 \mathrm{bp}$, while the $\mathrm{Y}$ allele is cut in three fragments of 232, 59 and $29 \mathrm{bp}$. Among our cases, one control case showed the $\mathrm{C} / \mathrm{Y}$ genotyping (5\%) and 19 case are wild type $\mathrm{C} / \mathrm{C}(95 \%)$. Among autism cases, only the wild type $\mathrm{C} / \mathrm{C}$ is present and no heterozygotes $\mathrm{C} / \mathrm{Y}$ was detected. Among both autism and control cases, no homozygotes $\mathrm{Y} / \mathrm{Y}$ was present (Table 2). This is considered a genetic cause of iron metabolism disorder haemochromatosis [1]. Our results agree with previous studies for the $\mathrm{C} 282 \mathrm{Y}$ genotype in neurodegenerative disorders, which showed the $\mathrm{Y}$ allele as a rare allele with no association with these disorders.
In the autism group, the frequency of the $\mathrm{C}$ allele is $100 \%$, and in the controls the $\mathrm{C}$ allele frequency is $95 \%$ and for the $\mathrm{Y}$ allele is $5 \%$.

The alleles frequencies are in Hardy-Weinberg equilibrium. No significant effect of the $\mathrm{C}$ or the $\mathrm{Y}$ allele on the presence of autistic features was detected in the studied cases ( $p$ value $=0.09$ ), logistic regression analysis showing insignificant effect of neither age nor sex.

\section{Discussion}

Despite the increasing prevalence of autism worldwide, its biochemical and diagnostic markers are still unknown. Autism heritability is around 90\%, despite the difficulty in discovering autism causing genes [2]. Multiple studies of candidate genes have included more than hundred genes for association with autism with multiple positive results, these genes being classified to multiple functioning pathways [27].

Increased oxidative stress caused by either increased production or decreased elimination of oxygen free radicals was associated with cell damage in many neurodegenerative diseases, with AD and Parkinson disease being the commonly studied disorders [18]. Iron in its ferrous ion form catalyzes the formation of toxic hydroxyl radicals, and thus initiates and exaggerates lipid peroxidation and ultimately lead to brain cell destruction [15]. A role of oxidative stress as measured by intraerythrocyte non-protein-bound iron, F2-isoprostanes and others was evident in classic Rett syndrome [11], which shares many symptomatic and pathophysiological features with autism. A study done on Egyptian children with autism showed disturbed antioxidant enzymes; superoxide dismutase (SOD) and glutathione peroxidase (GSH-Px), and malondialdehyde (MDA) (a marker of lipid peroxidation) compared to controls [29].

Compensating factors that neutralize oxidative load include SOD, ceruloplasmin and transferrin (by de- 


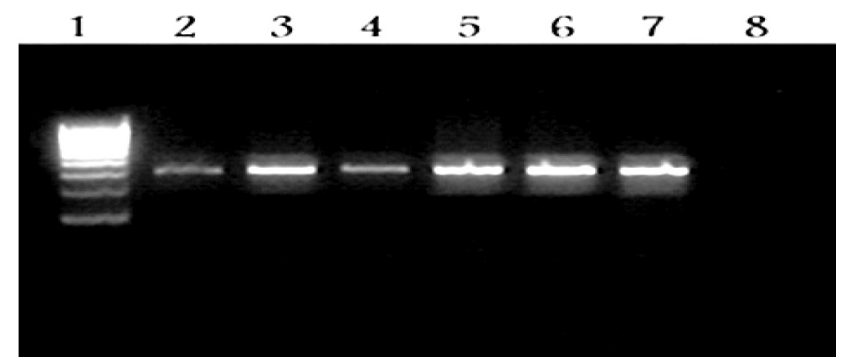

Fig. 2. C282Y PCR products on $2.5 \%$ agarose gel, lane 1 is hyperladder IV, lane $2-7$ show PCR products ( 320 bp), lane 8 is a PCR negative control (no DNA).

creasing cellular ferrous iron), with potent roles being implicated in autism [17,24].

The current study involves the two most common functional polymorphisms in the iron regulating gene HFE (p.H63D and p.C282Y) which are implicated in several neurodegenerative disorders. As the brain iron controlling proteins are still under extensive investigation to reveal the controlling factors across the blood brain barrier, evidences show that HFE protein plays a pivotal role in this metabolism [23].

This is the first study to include this gene in relation to autism, the aim of this study emerged from the recent studies that showed increased iron intake and disturbed iron metabolism as risk factors for autism and disturbed immune function [35], while other studies related specific symptoms in autism children as disturbed sleep pattern and iron intake [10]. This study does not show evidence of association of HFE polymorphisms with autism among our sample. The absence of association between HFE p.H63D and autism, although the D63 allele has been playing a risk role in neurodegenerative disorders e.g. AD, Parkinson's disease [16], and aging white matter lesions [31] could be referred to age related effect of the D allele and different CNS biological pathways that are disturbed in both disease groups. The main pathways that show changes in neurodegeneration include apoptosis, ion channels, proteolysis and cell cycle [19]. Increased oxidative stress in autism could be linked to decreased levels of transferrin (iron-binding protein) or ceruloplasmin (copper-binding protein) in the serum, and this was shown in a previous study with significant correlation with regression of acquired language skills [36]. Our study shows less evident role for the proteins responsible for intracellular iron pooling in the brain e.g. HFE protein.

Increased oxidative stress is thought to play a role in autism and neurodegenerative group. However, HFE gene function is also linked to immune function and glutamate transport. Other studies have shown that the expression of the D63 allele was associated with raised levels of calcium, greater secretion of glutamate, and reduced uptake of glutamate in neuroblastoma cell lines [33].

Other pathways that show disturbance in autism and other neurodevelopmental disorders include intrahemispheric connectivity involving white matter of the brain and intracortical connectivity (detected by functional MRI scan) [30].

The second studied polymorphism the $\mathrm{C} 282 \mathrm{Y}$ is shown to be rare among our studied samples, which was shown in other populations with an insignificant role of the Y282 as a risk allele for autism. This agreed with previous studies involved this polymorphism among neurological disorders [4,31]. This supports the role of the $\mathrm{C} 282 \mathrm{Y}$ polymorphism as a risk factor for liver iron metabolism diseases i.e. haemochromatosis and not in neurological diseases.

To conclude, although oxidative stress has been implicated for a role in autism spectrum disorder the exact role of iron and genes controlling its metabolism is still undetermined. Iron storage parameters e.g. ferritin might have an indicative role of the iron status in the central nervous system and thus oxidative stress in these cells. Other extended studies that include iron genes and proteins expression in autism children would be of critical value in outlining the main changes in this complicated pathway in relation to oxidative stress parameters.

\section{Acknowledgement}

We would like to thank all children participated in this study and their families.

\section{References}

[1] A. Gnirke, J.N. Feder, W. Thomas, Z. Tsuchihashi, D.A. Ruddy, A. Basava, F. Dormishian, R. Domingo, Jr., M.C. Ellis, A. 
Fullan, L.M. Hinton, N.L. Jones, B.E. Kimmel, G.S. Kronmal, P. Lauer, V.K. Lee, D.B. Loeb, F.A. Mapa, E. McClelland, N.C. Meyer, G.A. Mintier, N. Moeller, T. Moore, E. Morikang, C.E. Prass, L. Quintana, S.M. Starnes, R.C. Schatzman, K.J. Brunke, D.T. Drayna, N.J. Risch, B.R. Bacon and R.K. Wolff, A Novel Mhc Class I-Like Gene Is Mutated in Patients with Hereditary Haemochromatosis, Nature genetics 13(4) (1996), 399-408.

[2] A. Le Couteur, A. Bailey, I. Gottesman, P. Bolton, E. Simonoff, E. Yuzda and M. Rutter, Autism as a Strongly Genetic Disorder: Evidence from a British Twin Study, Psychol Med 25 (1995), 63-78.

[3] A. Settin, M. El-Bendary, R. Abo-Al-Kassem and R. El Baz, Molecular Analysis of A1AT (S and Z) and HFE (C282Y and H63D) Gene Mutations in Egyptian Cases with HCV Liver Cirrhosis, J Gastrointestin Liver Dis 15 (2006), 131-135.

[4] A. Waheed, S. Parkkila et al., Hereditary Hemochromatosis: Effects of C282y and H63d Mutations on Association with Beta2-Microglobulin, Intracellular Processing, and Cell Surface Expression of the Hfe Protein in Cos-7 Cells, Proc Natl Acad Sci USA 94 (1997), 12384-12389.

[5] American Psychiatric Association, 'Diagnostic and Statistical Manual of Mental Disorders, 4th Edn' 2000.

[6] American Psychiatric Association, 'Task Force on Dsm-Iv. Diagnostic and Statistical Manual of Mental Disorders: DSMIV-TR. 4th ed., Washington, DC, 2000.

[7] Association American Psychiatric, 'Diagnostic and Statistical Manual of Mental Disorders, 4th Edn, Text revision, Washington, DC, 2000

[8] J.G. Bodmer, E.D. Albert, W.F. Bodmer, R.E. Bontrop, D. Charron, B. Dupont, H.A. Erlich, R. Fauchet, B. Mach, W.R. Mayr, P. Parham, T. Sasazuki, G.M. Schreuder, J.L. Strominger, A. Svejgaard and P.I. Terasaki, 'Nomenclature for Factors of the Hla System', Tissue antigens 49 (1996), 297321.

[9] C.A. Enns, Possible Roles of the Hereditary Hemochromatosis Protein, Hfe, in Regulating Cellular Iron Homeostasis, Biol Res 39 (2006), 105-111.

[10] C.F. Dosman, J.A. Brian, I.E. Drmic, A. Senthilselvan, M.M. Harford, R.W. Smith, W. Sharieff, S.H. Zlotkin, H. Moldofsky and S.W. Roberts, Children with Autism: Effect of Iron Supplementation on Sleep and Ferritin, Pediatr Neurol 36 (2007), 152-158.

[11] C. De Felice, L. Ciccoli, S. Leoncini, C. Signorini, M. Rossi, L. Vannuccini, G. Guazzi, G. Latini, M. Comporti, G. Valacchi and J. Hayek, Systemic Oxidative Stress in Classic Rett Syndrome, Free Radic Biol Med 47 (2009), 440-448.

[12] E. Fombonne, R. Zakarian, A. Bennett, L. Meng and D. McLean-Heywood, Pervasive Developmental Disorders in Montreal, Quebec, Canada: Prevalence and Links with Immunizations, Pediatrics 118 (2006), 139-150.

[13] E. Gianazza, P. Arnaud and L. Miribel, Ceruloplasmin, Methods in enzymology 163 (1988), 441-452.

[14] E.H. Hanson, G. Imperatore et al., Hfe Gene and Hereditary Hemochromatosis: A Huge Review. Human Genome Epidemiology, Am J Epidemiol 154 (2001), 193-206.

[15] E.D. Day and J.M. McCord, Superoxide Dependent Production of Hydroxyl Radical Catalyzed by Iron-Edta Complex, FEBS Letters 86 (1978), 139-142.

[16] E.P. Simpson, A.A. Yen, J.S. Henkel, D.R. Beers and S.H. Appel, Hfe Mutations Are Not Strongly Associated with Sporadic Als, Neurology 62 (2004), 1611-1612.

[17] G. Perry, L.F. Gonzalez-Cuyar, H. Miyajima, C.S. Atwood, M. Riveros-Angel, P.F. Lyons, S.L. Siedlak, M.A. Smith and
R.J. Castellani, Redox Active Iron Accumulation in Aceruloplasminemia, Neuropathology 28 (2008), 466-471.

18] I.G. Onyango and S.M. Khan, Oxidative Stress, Mitochondrial Dysfunction, and Stress Signaling in Alzheimer's Disease, Curr Alzheimer Res 3 (2006), 339-349.

[19] J.E. Simpson, O. Hosny, S.B. Wharton, P.R. Heath, H. Holden, M.S. Fernando, F. Matthews, G. Forster, J.T. O'Brien, R. Barber, R.N. Kalaria, C. Brayne, P.J. Shaw, C.E. Lewis and P.G. Ince, Microarray Rna Expression Analysis of Cerebral White Matter Lesions Reveals Changes in Multiple Functional Pathways, Stroke 40 (2009), 369-375.

[20] J.K. Kern and A.M. Jones, Evidence of Toxicity, Oxidative Stress, and Neuronal Insult in Autism, J Toxicol Environ Health B Crit Rev 9 (2006), 485-499.

[21] J. Kato, M. Kobune, S. Ohkubo, K. Fujikawa, M. Tanaka, R. Takimoto, K. Takada, D. Takahari, Y. Kawano, Y. Kohgo and Y. Niitsu, Iron/Irp-1-Dependent Regulation of Mrna Expression for Transferrin Receptor, Dmt1 and Ferritin During Human Erythroid Differentiation, Exp Hematol 35 (2007), 879-887.

[22] J.N. Feder, A. Gnirke, W. Thomas, Z. Tsuchihashi, D.A. Ruddy, A. Basava, F. Dormishian, R. Domingo, Jr., M.C. Ellis, A. Fullan, L.M. Hinton, N.L. Jones, B.E. Kimmel, G.S. Kronmal, P. Lauer, V.K. Lee, D.B. Loeb, F.A. Mapa, E. McClelland, N.C. Meyer, G.A. Mintier, N. Moeller, T. Moore, E. Morikang, C.E. Prass, L. Quintana, S.M. Starnes, R.C. Schatzman, K.J. Brunke, D.T. Drayna, N.J. Risch, B.R. Bacon and R.K. Wolff, A Novel Mhc Class I-Like Gene Is Mutated in Patients with Hereditary Haemochromatosis, Nat Genet 13 (1996), 399408.

[23] J.A. Lebron, M.J. Bennett and P.J. Bjorkman, Crystal Structure of the Hereditary Haemochromatosis Protein Hfe Complexed with Transferrin Receptor, Nature 403 (2000), 46-53.

[24] K. Pantopoulos and D. Galaris, Oxidative Stress and Iron Homeostasis: Mechanistic and Health Aspects, Critical Reviews in Clinical Laboratory Sciences 45 (2008), 1-23.

[25] M.J. Bennett, J.A. Lebron and P.J. Bjorkman, Crystal Structure of the Hereditary Haemochromatosis Protein Hfe Complexed with Transferrin Receptor, Nature $\mathbf{4 0 3}$ (2000), 46-53.

[26] M. Rutter, Genetic Studies of Autism: From the 1970s into the Millennium, J Abnorm Child Psychol 28 (2000), 3-14.

[27] M. State and A. Gupta, Autism: Genetics, Rev Bras Psiquiatr 28 (2006), 29-38.

[28] M.J. Greenway, E.F. Goodall, I. van Marion, C.B. Carroll, O. Hardiman and K.E. Morrison, Association of the H63d Polymorphism in the Hemochromatosis Gene with Sporadic Als, Neurology 65 (2005), 934-937.

[29] N.A. Meguid, A.A. Dardir, E.R. Abdel-Raouf and A. Hashish, Evaluation of Oxidative Stress in Autism: Defective Antioxidant Enzymes and Increased Lipid Peroxidation, Biol Trace Elem Res.

[30] N.J. Minshew and D.L. Williams, The New Neurobiology of Autism: Cortex, Connectivity, and Neuronal Organization, Arch Neurol 64 (2007), 945-950.

[31] O.H. Gebril, J. Kirby, G. Savva, C. Brayne and P.G. Ince, Hfe H63d, C282y and Agtr1 A1166c Polymorphisms and Brain White Matter Lesions in the Aging Brain, J Neurogenet (2011).

[32] Q. Wang, Z. Qian and Y. Pu, Brain Iron and Neurological Disorders, Chin Med J (Engl) 110 (1997), 455-458.

[33] S. Lee, X.S. Wang, Z. Simmons, P. Boyer, K. Scott, W. Liu and J. Connor, Increased Incidence of the Hfe Mutation in Amyotrophic Lateral Sclerosis and Related Cellular Consequences, Journal of the Neurological Sciences 227 (2004), 27-33. 
[34] S. Sanchez-Iglesias, P. Rey, E. Mendez-Alvarez, J.L. Labandeira-Garcia, and R. Soto-Otero, Time-Course of Brain Oxidative Damage Caused by Intrastriatal Administration of 6-Hydroxydopamine in a Rat Model of Parkinson's Disease, Neurochem Res 32 (2007), 99-105.

[35] U. Padhye, Excess Dietary Iron Is the Root Cause for In- crease in Childhood Autism and Allergies, Med Hypotheses 61 (2003), 220-222.

[36] V. Chauhan, A. Chauhan, W.T. Brown and I. Cohen, Oxidative Stress in Autism: Increased Lipid Peroxidation and Reduced Serum Levels of Ceruloplasmin and Transferrin - the Antioxidant Proteins, Life Sciences 75 (2004), 2539-2549. 


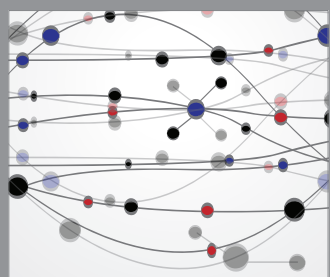

The Scientific World Journal
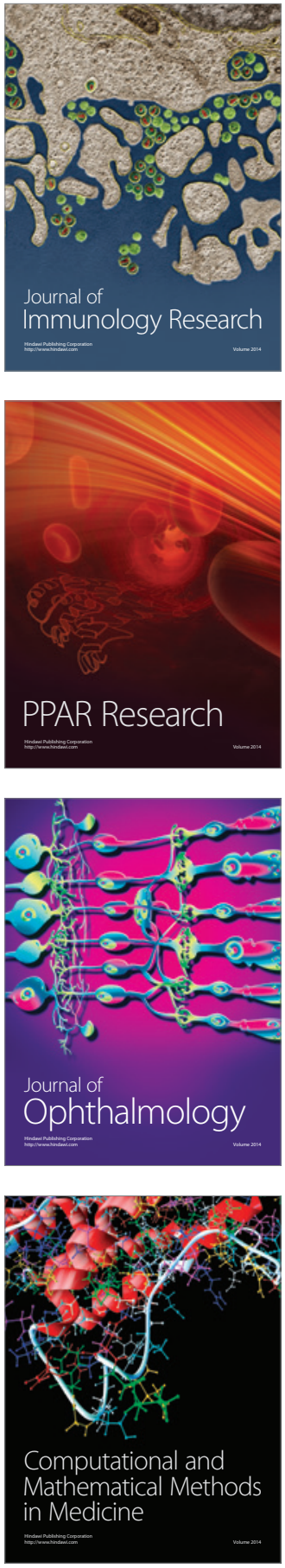

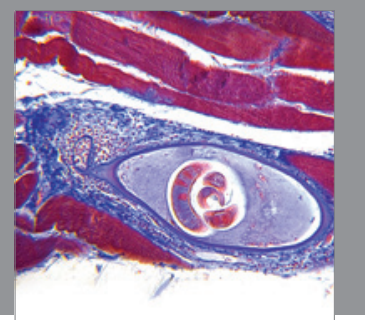

Gastroenterology

Research and Practice
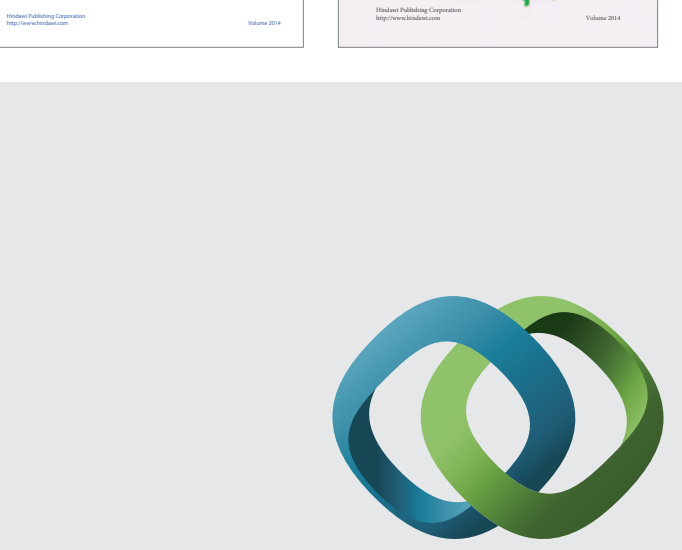

\section{Hindawi}

Submit your manuscripts at

http://www.hindawi.com
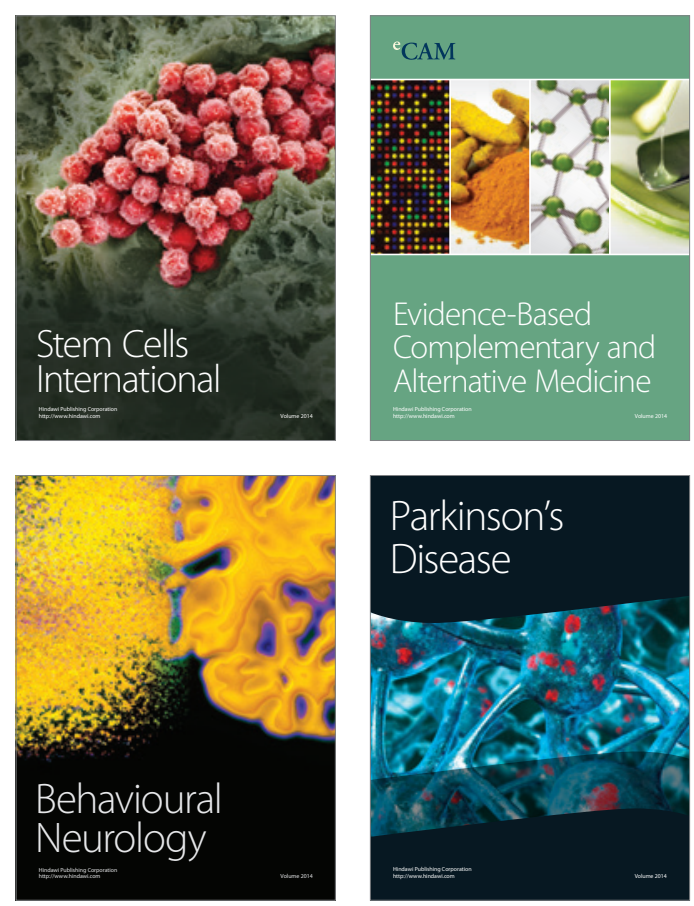

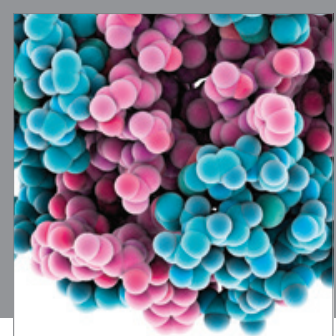

Journal of
Diabetes Research

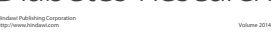

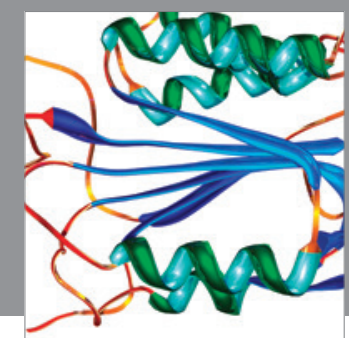

Disease Markers
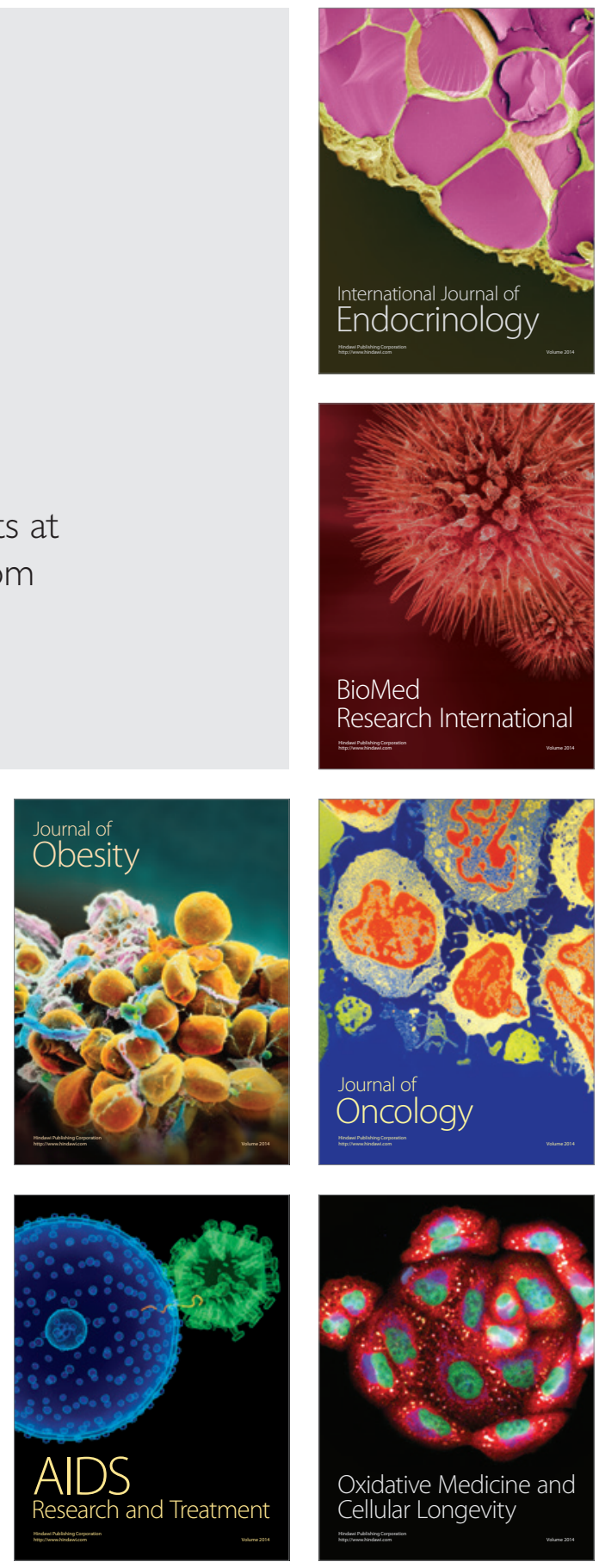